\title{
Article \\ Geology and Petrogeochemistry of Lijiapuzi Nb-Ta Granitic Pegmatite Deposit: Implications for Ore Genesis and Prospecting
}

\author{
Jianfei Fu ${ }^{1}$, Yuzeng Yao ${ }^{1} * \mathbb{B}$, Jing Liu ${ }^{1}$, Zining $\mathrm{Li}^{1}$, Sanshi Jia ${ }^{2}$ and Yemao Pang ${ }^{3}$ \\ 1 Department of Geology, Northeastern University, Shenyang 110004, China; fujianfei@mail.neu.edu.cn (J.F.); \\ 2100986@stu.neu.edu.cn (J.L.); 2100985@stu.neu.edu.cn (Z.L.) \\ 2 School of Resource and Materials, Northeastern University at Qinhuangdao, Qinhuangdao 066004, China; \\ yz_yao@126.com \\ 3 No.101 Geology Team Co., Ltd., Liaoning Nonferrous Geology Bureau, Fushun 113015, China; \\ yzyao@21cn.com \\ * Correspondence: yaoyuzeng@mail.neu.edu.cn
}

check for

updates

Citation: Fu, J.; Yao, Y.; Liu, J.; Li, Z.; Jia, S.; Pang, Y. Geology and Petrogeochemistry of Lijiapuzi Nb-Ta Granitic Pegmatite Deposit: Implications for Ore Genesis and Prospecting. Appl. Sci. 2022, 12, 2542. https://doi.org/10.3390/ app12052542

Academic Editors: Stanisław Z. Mikulski and Adam Piestrzyński

Received: 20 December 2021

Accepted: 24 February 2022

Published: 28 February 2022

Publisher's Note: MDPI stays neutral with regard to jurisdictional claims in published maps and institutional affiliations.

Copyright: () 2022 by the authors Licensee MDPI, Basel, Switzerland. This article is an open access article distributed under the terms and conditions of the Creative Commons Attribution (CC BY) license (https:/ / creativecommons.org/licenses/by/ $4.0 /)$.

\begin{abstract}
Most of the rare metal pegmatite deposits in China lie in West, Central and South China, and the Lijiapuzi $\mathrm{Nb}$-Ta deposit is the only pegmatite-type $\mathrm{Nb}$-Ta deposit in Northeast China, therefore a detailed study of the Lijiapuzi deposit is of great importance to the metallogeny and exploration of rare metal deposits in Northeast China. The $\mathrm{Nb}$-Ta bearing pegmatites in Lijiapuzi district are composed of a microcline wall zone, a muscovite (lepidolite)-albite intermediate zone and a quartz core, and the rare metal mineralization mainly occurs in the intermediate zone and is intimately related to the albitization. The lithogeochemical features indicate that Lijiapuzi pegmatoids are rich in silicon and alkaline, poor in calcium, magnesium, titanium and phosphorus, and belong to peraluminous granitoid rocks. The enrichment of large ion lithophile elements (LILEs) and depletion of high field-strength elements (HFSEs), the distinct right-inclined REE pattern with obvious Eu negative anomaly, lower ratio of $\mathrm{Nb} / \mathrm{Ta}$ and higher ratio of $\mathrm{La} / \mathrm{Nb}$ and $\mathrm{Rb} / \mathrm{Sr}$ indicate that the pegmatite was of a crustal origin and formed in relatively extensional tectonic setting of postorogenesis. The pegmatites in Lijiapuzi area can be divided into two categories, i.e., the NW-trending pegmatites are shorter and thicker, with obvious zoning and localized in the upper part of the nearsurface, while the NE-trending pegmatites are longer, thinner, devoid of zoning and localized in the lower part of the district. This probably means that excellent ore prospecting potential exists in the lower part of the Lijiapuzi district.
\end{abstract}

Keywords: Nb-Ta deposit; pegmatite; LCT type; metallogeny; Lijiapuzi deposit

\section{Introduction}

Rare metals are essential to modern industry, especially high-tech industries such as micro-electronics, specialty alloys and high-strength low-alloys etc., [1-4], which are regarded as strategic and critical metals [3-6]; however, their production has long been limited in a few countries, and thus their resources, types of deposit, origin, genesis, and tectonic settings attract attention worldwide [7-10]. Globally the Ta resources mainly occur in pegmatites and rare element-enriched peraluminous granites [3,4,6]; consequently, pegmatites had long been the foci of metallogenic research.

The inherent coarse-grained and in most cases zoning features make the pegmatites distinct from common rocks with similar composition, resulting in the precise determination of the bulk composition of the entire pegmatite almost impossible [11]. Even a simple classification schedule is difficult for pegmatites, as summarized by some scholars [11,12]. Currently, the five-class depth-zone classification [13] and its revision scheme [14], combined with the family classification [8], are the most widely used for granitic pegmatites. 
The prominence of the scheme is to introduce the geochemical subdivision of the rare element pegmatite class into three families: the niobium- yttrium-fluorine (NYF) family, the lithium-cesium-tantalum (LCT) family, and the mixed NYF-LCT family. Furthermore the NYF-LCT subdivision has become independent from the depth zone classification and been used to distinguish pegmatites of the other four classes as well [12].

In China, pegmatite deposits are one of the most important rare metal metallogenetic types [15-17], e.g., the famous Koktokay pegmatite in Altai $[18,19]$ and the recently discovered Renli high-grade super-large Nb-Ta deposit in Hunan Province [20], indicating a conspicuous mineral resource potential. However, the granitic pegmatoid $\mathrm{Nb}$-Ta deposits discovered so far in China are mainly concentrated in West, Central and South China. The Lijiapuzi Nb-Ta deposit, exploited in the 1970s as a muscovite deposit and confirmed to be a Nb-Ta pegmatite deposit in 2018, is the only pegmatite-type rare metal deposit proven by systematic exploration in Northeast China. Considering that both the Zhaojinggou granitic pegmatite $\mathrm{Nb}$-Ta deposit in Inner Mongolia [21,22] and the Lijiapuzi pegmatite $\mathrm{Nb}$-Ta deposit locate at the northern margin of North China Craton, this probably indicates that there is a large-scale rare element mineralization in this area. From this point of view, the detailed study on the metallogeny of the Lijiapuzi deposit is of great importance to evaluation of the resource potential of rare metals in Northeast China.

\section{Geological Setting}

North China Craton (NCC), compared to the adjacent Central Asian Orogenic Belt in the north and the Central China Orogenic Belt (Qinling-Dabie Orogenic Belt) in the south, is a relatively stable block (Figure 1). The NCC is composed of a Western Block and an Eastern Block, separated by the north-trending Trans-North China Orogen (TNCO), which developed through a series of subduction-related systems and occurred as the suture zone between the two blocks $[23,24]$. The TNCO and the marginal zones of NCC reactivated in the late tectonomagmatic activities, especially during the Mesozoic collision between the Pacific Plate and the Eurasian Plate, and resulted in the formation of various mineral deposits, i.e., most of the hydrothermal ore deposits are distributed along TNCO and the marginal zones of the NCC [24-26].

The Lijiapuzi Nb-Ta deposit, ca.110 km southeast of Shenyang city (the capital of Liaoning Province), with longitude $124^{\circ} 48^{\prime} 13^{\prime \prime}$ E and latitude $41^{\circ} 27^{\prime} 46^{\prime \prime} \mathrm{N}$, lies in the eastern margin of the NCC. Regionally, the most widely spread strata is Archean highgrade metamorphic rocks of the Anshan group, whose lithology includes plagioclase amphibolites, biotitic granulites, amphibole gneiss, migmatitic granite and banded iron formation. The Sinian shale and limestone are scattered in the south part of the research area. The phanerozoic cover layers are mainly quartz sandstone, limestone, and Mesozoic continental volcano-sedimentary formation such as tuff, shale, and volcanic breccias, which as a whole lies unconformably upon the highly deformed and metamorphosed Archean basement (Figure 1).

Since the formation of the ancient basement rocks, the studying area had experienced multiple periods of magmatism and fracturing, which was beneficial to the migration of hydrothermal fluids and the filling of dykes and veins. Regionally there occur three groups of structures, i.e., the EW trending structures which control the spatial distribution of the Archean basement; the NE- and NW-trending structures are intimately related to the Cambrian and Mesozoic volcanic sedimentary basins [27].

There are two kinds of magmatic rocks in the studying area. One is the Archean anatectic granite; the strong migmatization of volcano-sedimentary rocks was considered to be related to the formation of granitic pegmatites and also to the $\mathrm{Nb}$-Ta mineralization [27]. The other is the intense Mesozoic volcanic-subvolcanic-intrusive rocks, including Jijiapuzi granite, ca. $6 \mathrm{~km}$ north of the Lijiapuzi deposit with a total exposure area of $120 \mathrm{~km}^{2}$ that has resulted in a more than $100 \mathrm{~km}^{2}$ alteration zone which indicates as pyritization, silification, and epidotization etc. In addition, there was a lot of intermediate to acid dykes such as granite, granitic porphyry, diorite, quartz vein, etc. in the area. 

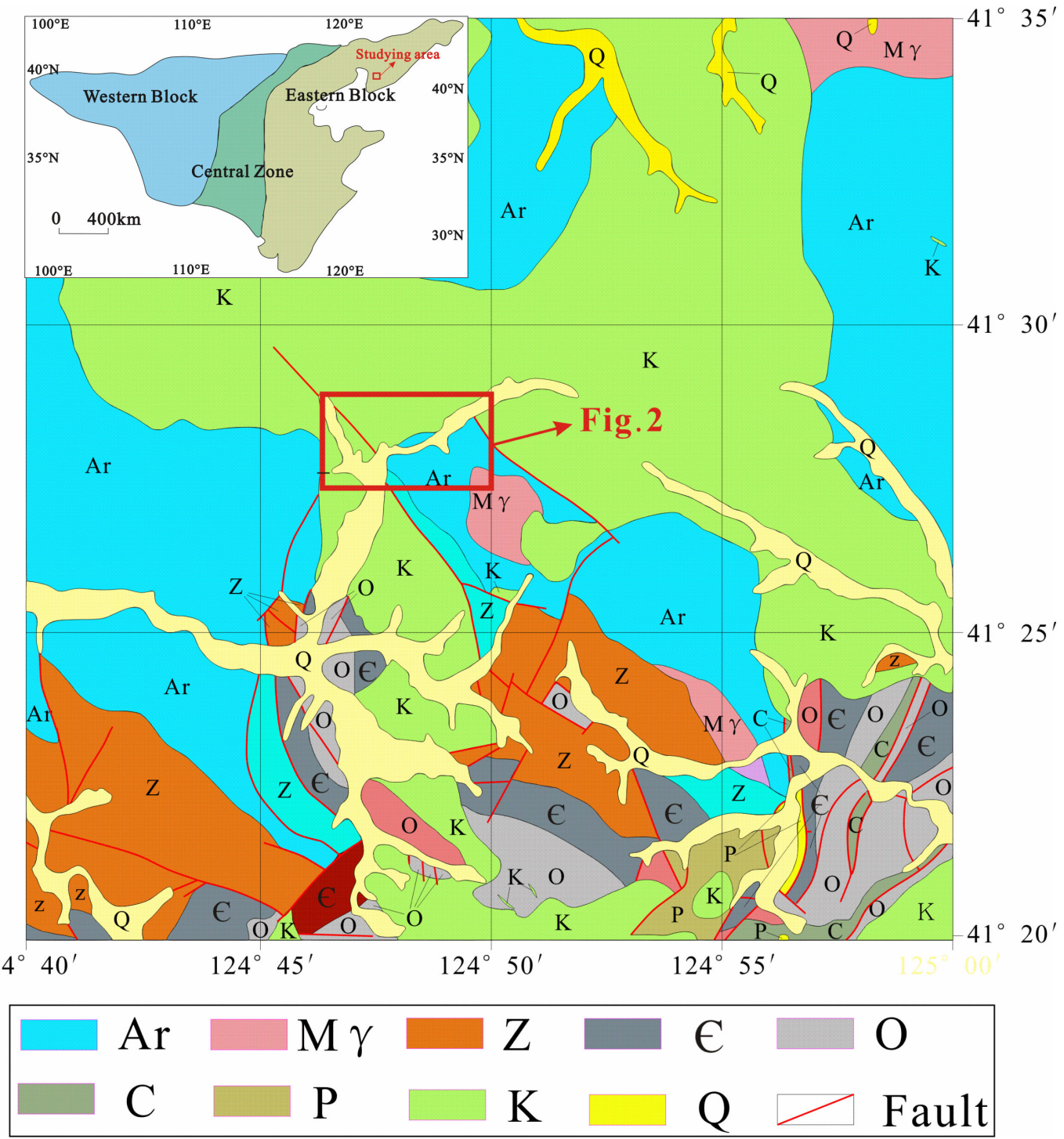

Figure 1. Regional geologic map of Lijiapuzi. Ar-Archean metamorphic rocks; $\mathrm{M} \gamma$-Archean migmatitic granite; Z-Sinian shale and limestone; $\in$-bitumen bearing shale and limestone; $\mathrm{O}$ dolomitic limestone; C-carbonaceous shale; P-quartz sandstone; K-sandstone interlayer with andesite; Q-quaternary.

\section{Ore Deposit Geology}

The lithology that occurred in Lijiapuzi mining district is mainly that of Archean metamorphic rocks and Mesozoic andesite and tuff (Figure 2). The former was metamorphosed so intensely that migmatization occurred widely in the mining area. The $\mathrm{Nb}$-Ta bearing pegmatites were believed to be related to the regional migmatization in the southeastern part of the mining area [27], partially owing to the isotopic dating of muscovite in the pegmatites ranging from $2395 \mathrm{Ma}$ to $2464 \mathrm{Ma}$ (Yonghong Zhang, No. 101 Geological Team Co., Ltd, Liaoning Nonferrous Geology Bureau, Fushun, P. R. China; Unpublished work). The Mesozoic volcanic activities led to the reactivation and superimposition of the brittle fractures upon the ancient basement. The faults in the mining area can be divided into two categories, i.e., the NE trending Lijiapuzi overthrust fault, which dips to the SE with an angle of $40-60^{\circ}$, and the NW trending Dabuqiyan overthrust fault, which dips to the NE with an angle $40-60^{\circ}$. Both the faults are compressive-shearing, conjugated, and belong to the same tectonic stress field. 


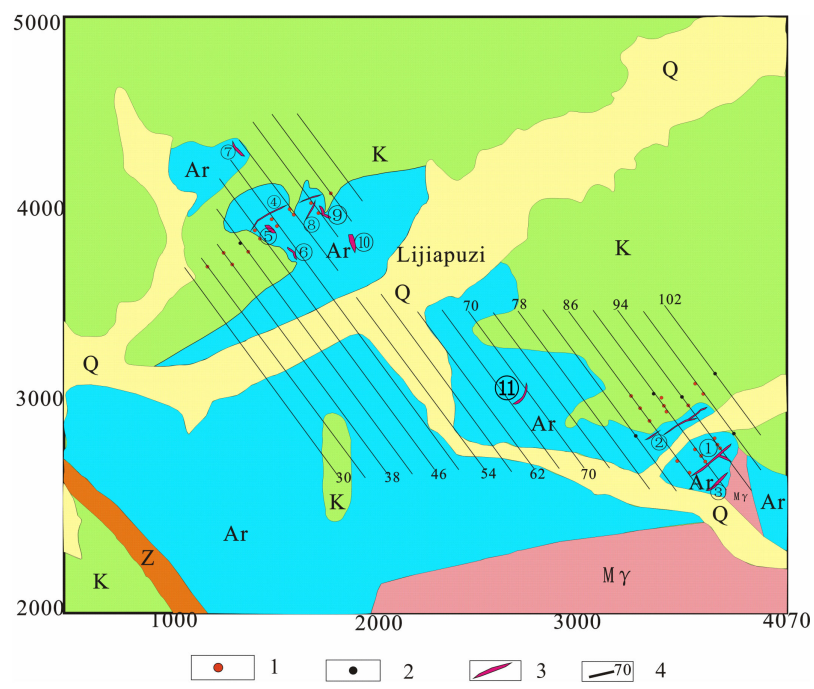

Figure 2. Geological map of Lijiapuzi Nb-Ta deposit. Lithology is the same as Figure 1B. 1mineralization borehole; 2-non-mineralization borehole; 3-pegmatite ore bodies; 4-sections.

The detailed exploration of the Lijiapuzi deposit began in 2008 and finished in 2018 [28]. A total of $11 \mathrm{Nb}$-Ta bearing pegmatites were explored, with an average of $0.0045 \% \mathrm{Nb}_{2} \mathrm{O}_{5}$ and $0.0312 \% \mathrm{Ta}_{2} \mathrm{O}_{5}$ (Table 1). Generally the NE-trending pegmatites are longer but thinner, echelon arranged with relatively regular shape such as the vein-type, have large extension depth and weak or no differentiation. The NW-trending pegmatites are shorter but thicker, and usually occur near the surface with small extension depth and relatively irregular shapes such as lenticular and well-differentiated [27]. All the pegmatites are localized in Archean metamorphic rocks. Note that No.1, No.2 and No.9 pegmatite are composed of both the NE-trending and NW-trending sub-fractures, and the pegmatite dikes occur as a whole, indicating that the pegmatite-controlling fractures were formed contemporarily and probably conjugated.

Table 1. The general characteristics of $\mathrm{Nb}$-Ta bearing pegmatites in Lijiapuzi deposit (Adapted from ref. [28]).

\begin{tabular}{|c|c|c|c|c|c|c|}
\hline \multirow[b]{2}{*}{ Ore Body } & \multicolumn{2}{|c|}{ Ore Body Size } & \multicolumn{2}{|c|}{ Grade (\%) } & \multicolumn{2}{|c|}{ Occurrence } \\
\hline & Length (m) & $\begin{array}{c}\text { Average } \\
\text { Thickness (m) }\end{array}$ & $\mathrm{Nb}_{2} \mathrm{O}_{5}$ & $\mathrm{Ta}_{2} \mathrm{O}_{5}$ & Dip Direction & Dip Angle \\
\hline (1) & 238 & 0.83 & 0.0038 & 0.0339 & $305^{\circ}$ & $75^{\circ}$ \\
\hline (2) & 156 & 0.99 & 0.0040 & 0.0319 & $315^{\circ}$ & $75^{\circ}$ \\
\hline (2) -1 & 163 & 1.99 & 0.0074 & 0.0330 & $315^{\circ}$ & $65^{\circ}$ \\
\hline (3) & 90 & 0.12 & 0.0028 & 0.0320 & $325^{\circ}$ & $85^{\circ}$ \\
\hline (4) & 648 & 1.21 & 0.0051 & 0.0298 & $145^{\circ}$ & $75^{\circ}$ \\
\hline (5) & 42 & 3.39 & 0.0022 & 0.0510 & $55^{\circ}$ & $40^{\circ}$ \\
\hline (6) & 26 & 1.87 & 0.0035 & 0.0475 & $40^{\circ}$ & $50^{\circ}$ \\
\hline (7) & 112 & 0.37 & 0.0020 & 0.0158 & $40^{\circ}$ & $65^{\circ}$ \\
\hline$(8)$ & 100 & 0.28 & 0.0020 & 0.0592 & $295^{\circ}$ & $40^{\circ}$ \\
\hline (9) & 31 & 0.99 & 0.0036 & 0.0549 & $25^{\circ}$ & $75^{\circ}$ \\
\hline (10) & 35 & 0.27 & 0.0020 & 0.0254 & $70^{\circ}$ & $55^{\circ}$ \\
\hline (11) & 102 & 0.50 & 0.0033 & 0.0351 & $302^{\circ}$ & $65^{\circ}$ \\
\hline
\end{tabular}


The common differentiation in pegmatites manifests as the microcline wall zone, the albite intermediate zone, and the quartz core whose boundaries are obscure (Figures 3A and $4 \mathrm{~B})$. In most cases, the aplite border zone, usually ubiquitous in other rare metal pegmatites [10], is absent in the Lijiapuzi ore district.



$\mathrm{B}$
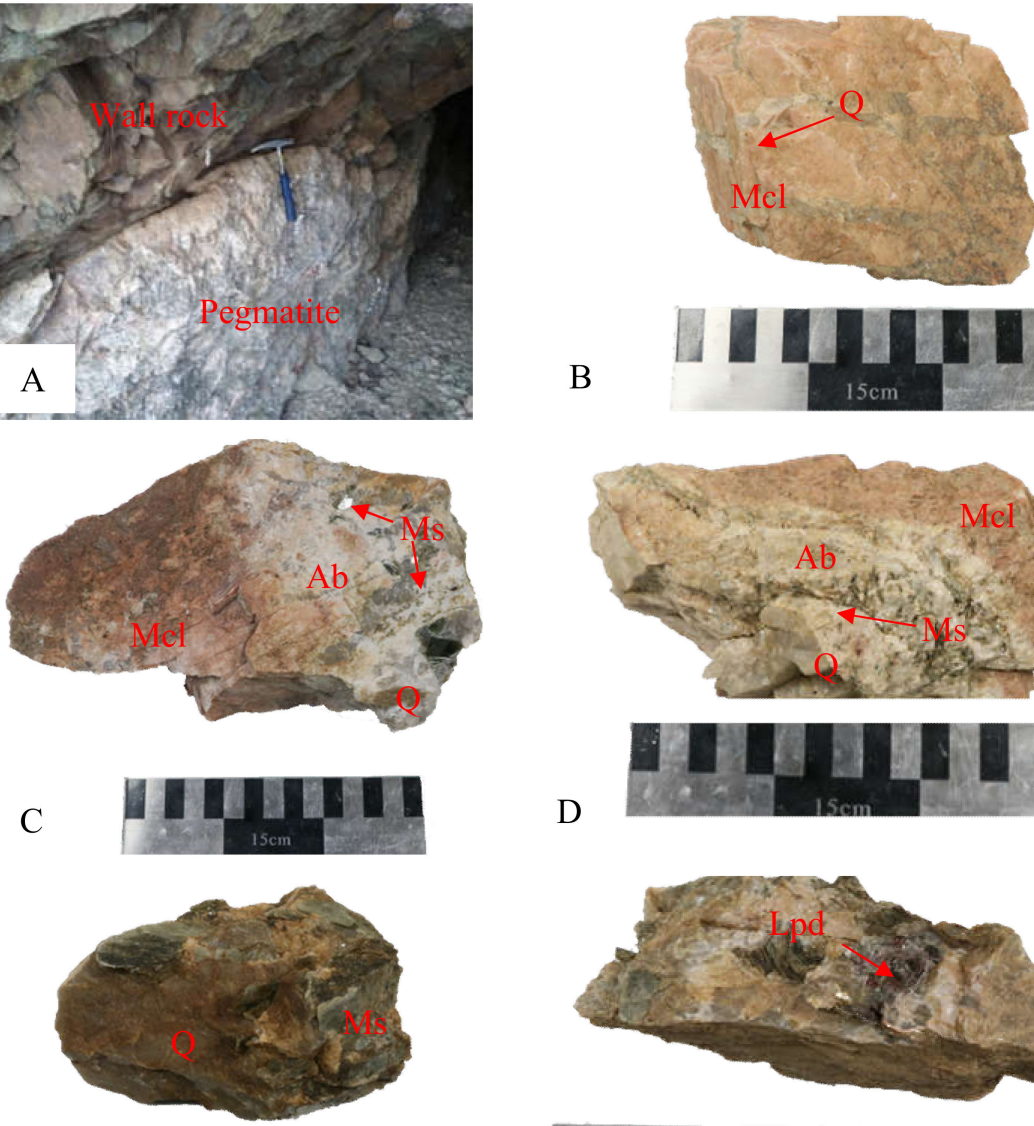

D
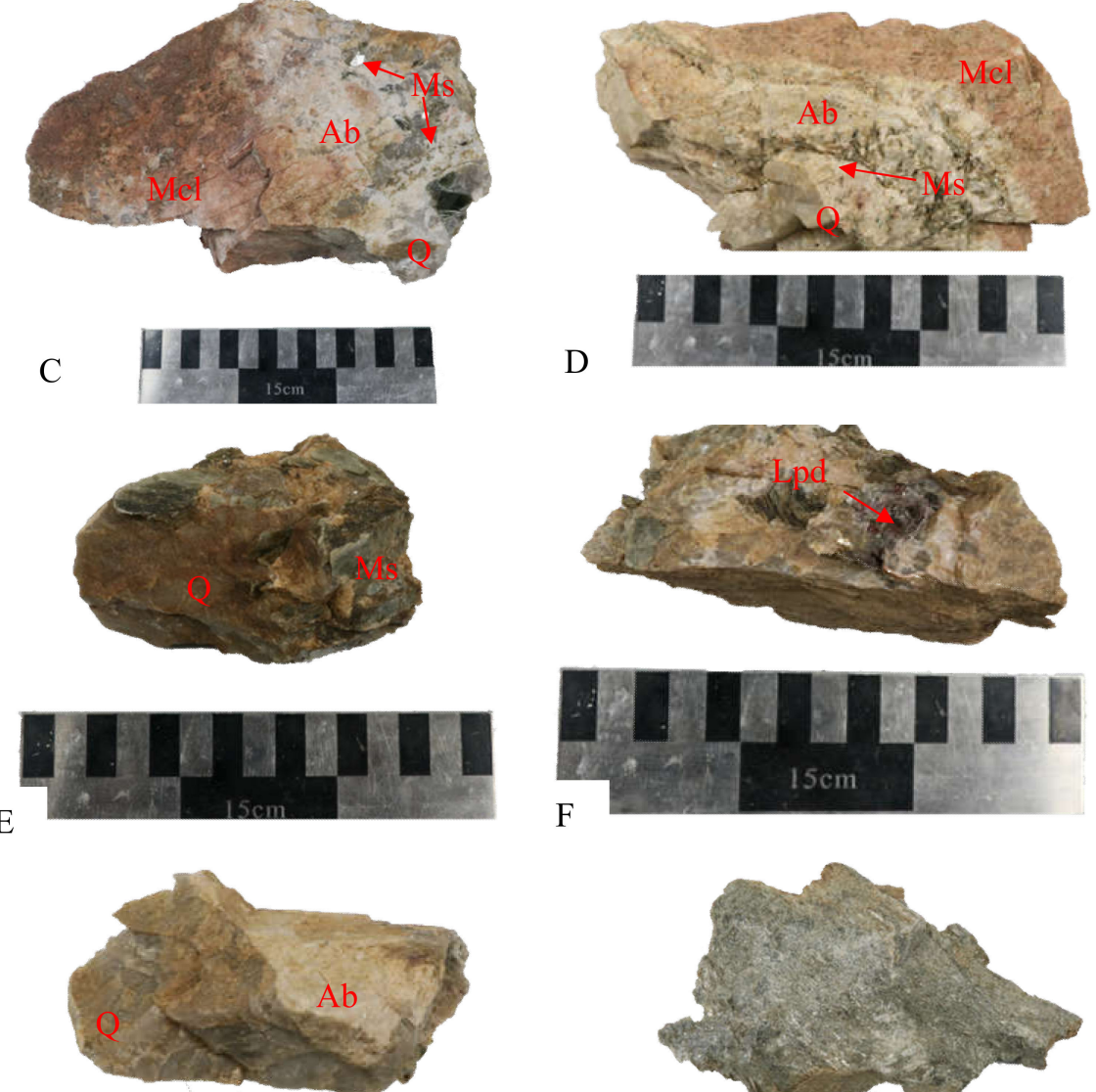

F

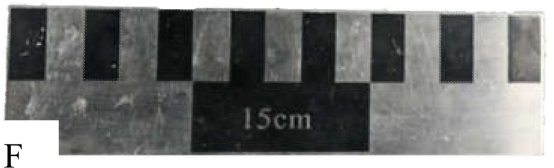

G

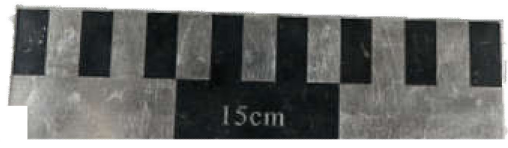

$\mathrm{H}$

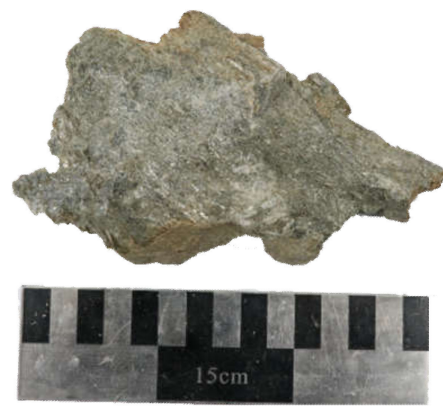

Figure 3. Field occurrence of pegmatites in the Lijiapuzi Nb-Ta ore deposit. (A) An abandoned mining gallery; (B) Marginal microcline rock sample, with late quartz veinlets filled in the fractures; (C,D) Transitional albite rock sample, with gradual or irregular boundary; (E) Sample close to quartz core, with greenish muscovite; (F) purple lepidolite; $(\mathbf{G})$ quartz core; $(\mathbf{H})$ Chloritized plagioclase amphibolite; Mcl-microcline; Q-quartz; Ab-albite; Ms-muscovite; Lpd-lepidolite. 



Figure 4. The main minerals in the Lijiapuzi pegmatite deposit (Transmitted cross-polarized light). (A) microcline with crossed twinning, with weak alteration; (B) albitization of microcline with an irregular contact boundary between them; (C) spodumene; (D) muscovite, fractured perpendicular to cleavages and filled by late metallic minerals; (E) apatite; (F) chloritization of plagioclase amphibolites; Mcl-microcline; Ab-albite; Q-quartz; Spd-spodumene; Ms-muscovite; Apt-apatite; Chl-chlorite; Tour-tourmaline.

In the wall zone, the pegmatite is mainly composed of microcline, quartz and a small amount of garnet, with either a minor amount or no muscovite at all (Figure 3B). In some cases there are quartz-veinlets dispersed in the wall zone, resulting in weak montmorillonitization of the microcline (Figure $4 \mathrm{~A}$ ). In addition, there are few sulfide minerals (Figure $5 \mathrm{~A}, \mathrm{~B}$ ) ore $\mathrm{Nb}$-Ta minerals. The intermediate zone differs from the wall zone by replacement of the microcline by albite (Figure 3C,D) with irregular boundaries (Figure 4B) and the appearance of massive greenish muscovite (Figure $3 \mathrm{E}$ ), and occasionally purple lepidolite (Figure 3F), spodumene (Figure 4C), apatite (Figure 4E), and minor beryl, gahnite, cassiterite and zircon [27]. The $\mathrm{Nb}$-Ta minerals such as tantalite and columbite, including microlite [27], were formed along the margin of albite (Figure 5E,F), indicating that the rare metal mineralization was intimately related to the albitization. Locally the mineral grains of early stages such as quartz, microcline, albite and muscovite were fractured and filled by epigenetic hydrothermal minerals. Laser Raman spectroscopy indicates that the opaque minerals involved are needle-like goethite along the cleavage or fractured margin of muscovite (Figures $4 \mathrm{D}$ and $5 \mathrm{C}$ ), accompanied by the accumulation of uranium minerals such as 
calciouranoite (Figure 5D), which means there should have been an epigenetic hydrothermal mineralization after the formation of the $\mathrm{Nb}$-Ta mineralization [28]. The paragenesis of goethite and uranium minerals is well in accordance with the mineralization pattern of a unconformity-type uranium deposit [29], and so is the Lijiapuzi, which is considered to be of supergene stage [27]. Where the pegmatites become thicker, or locally dilative, for instance, the thicker NW-trending pegmatites with the high differentiation of pegmatite will result in a pure quartz core, with minor or no other minerals (Figure 3G). The miarolitic cavities are seldom seen throughout the mining area.
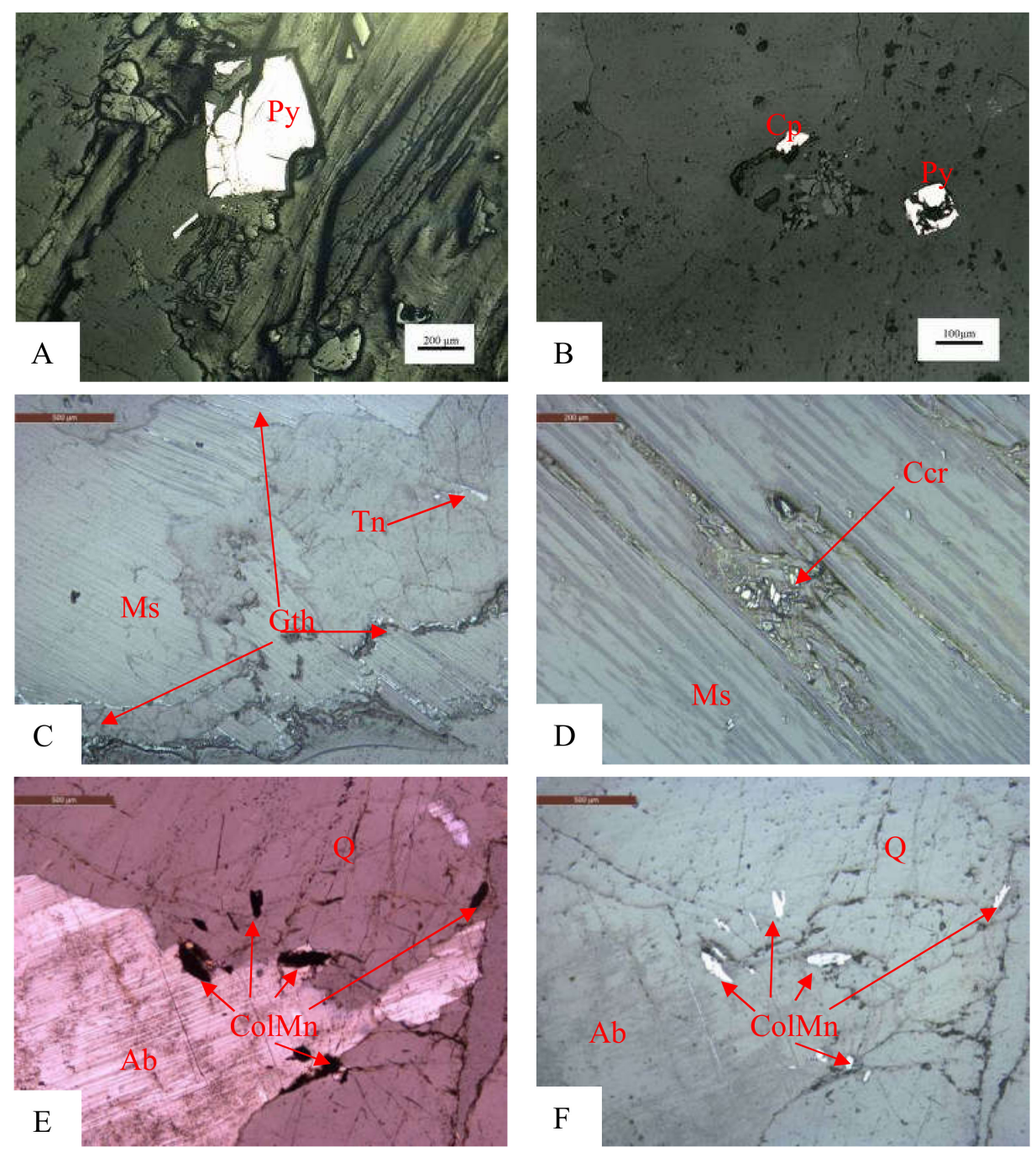

Figure 5. The major metallic minerals in the Lijiapuzi ore deposit. (A) Disseminated granular pyrite; (B) Paragenesis of chalcopyrite and pyrite; (C) Euhedral needle goethite along the cleavage and margin of muscovite, tantalite occurs as enclaves of quartz; (D) Cleavage of muscovite is metasomatized and filled with calciouranoite minerals; (E,F) ColumbiteMn distribute along the margin of albite; Py-pyrite; Cp-chalcopyrite; Ms-muscovite; Tn-tantalite; Gth-goethite; Ccr-calciouranoite; ColMn-columbiteMn; Q-quartz. Notes: (A-D) are under reflected light; $(\mathbf{E}, \mathbf{F})$ are identically the same image, $\mathrm{E}$ is under transmitted cross-polarized light while $\mathrm{F}$ is under reflected light.

The wall rock alteration is weak in the Lijiapuzi ore district. Where the pegmatites are thick, especially the flanks around the local dilation parts of the pegmatites, the relatively strong alteration manifests as the chloritization of biotite and hornblende (Figure $3 \mathrm{H}$ ), and occasionally there occurs some volatile components such as tourmaline in the host rocks (Figure 4F). 
Based on the mineral assemblages mentioned above, the pegmatites in Lijiapuzi district belong to the LCT type [13,14].

\section{Samples and Methods}

The Lijiapuzi pegmatite deposit was first discovered in 1960s and exploited in the 1970s for mica mining. By 2018, a total of 34 boreholes had been drilled, and all the cores had been preserved in the Geological Data Center Co., Ltd., Liaoning Geological Exploration and Mining Group, Shenyang, and core sampling was forbidden. Fortunately, four abandoned mining galleries were left over near the surface (Figure 3A). Twelve rock samples from the local dilation part of No.1 pegmatite were collected from No.2 gallery, among which three were from the wall zone, eight were from the intermediate zone, and one was from the quartz core. All the samples were sliced, part of each sample was sent for the preparation of polished and thin sections, and the other was used for geochemical assay at ALS Chemex (Guangzhou) Co. Ltd.

The bulk chemical compositions were determined by an X-ray fluorescence spectrometer (PANalytical PW2424, Almelo, The Netherlands). The mixture of lithium borate and lithium nitrate were added as melting flux into one piece of rock sample powder, fully mixed and then melted at high temperature. The molten substance was poured into the platinum mold to form a flat slide and then analyzed with an X-ray fluorescence spectrometer. Meanwhile, another piece of powder was put into the muffle furnace and burned at $1000{ }^{\circ} \mathrm{C}$, then cooled and weighed. The weight difference before and after heating is the loss on ignition.

The contents of trace elements and rare earth elements were determined by inductively coupled plasma atomic emission spectrometry (ICP-AES) and inductively coupled plasma mass spectrometry (ICP-MS). The rock powder was digested with a mixture of perchloric acid, nitric acid, hydrofluoric acid and hydrochloric acid, and diluted with hydrochloric acid and then analyzed by ICP-AES (Agilent 5110, Palo Alto, USA). If the contents of $\mathrm{Bi}, \mathrm{Hg}$, $\mathrm{Mo}, \mathrm{Ag}$ and $\mathrm{W}$ were too high, the liquor samples were diluted and analyzed by ICP-MS (Agilent 7900, Palo Alto, USA). After the spectral interference between the elements was corrected, the final result was obtained.

\section{Results}

The geochemical data, including the contents of major, trace and REE elements of 12 pegmatite samples, are listed in Table 2 . The data and their petrogenic significance are summarized as follows.

Table 2. Major, trace and REE data for pegmatite in the Lijiapuzi ore deposit.

\begin{tabular}{|c|c|c|c|c|c|c|c|c|c|c|c|c|}
\hline \multirow{2}{*}{ Sample } & LJP-1 & LJP-2 & LJP-3 & LJP-4 & LJP-5 & LJP-6 & LJP-7 & LJP-8 & LJP-9 & LJP-10 & LJP-11 & LJP-12 \\
\hline & \multicolumn{3}{|c|}{ Wall Zone } & Core & \multicolumn{8}{|c|}{ Intermediate Zone } \\
\hline \multicolumn{13}{|c|}{ Major elements (wt\%) } \\
\hline $\mathrm{SiO}_{2}$ & 68.77 & 71.84 & 65.73 & 76.60 & 75.14 & 77.45 & 88.75 & 75.82 & 81.03 & 81.56 & 71.33 & 72.95 \\
\hline $\mathrm{Al}_{2} \mathrm{O}_{3}$ & 16.70 & 14.66 & 18.30 & 14.04 & 14.88 & 13.70 & 6.73 & 14.64 & 11.36 & 10.88 & 17.44 & 16.44 \\
\hline $\mathrm{TFe}_{2} \mathrm{O}_{3}$ & 0.41 & 0.40 & 0.37 & 0.53 & 1.13 & 0.65 & 0.51 & 0.85 & 1.12 & 0.83 & 1.18 & 0.53 \\
\hline $\mathrm{Na}_{2} \mathrm{O}$ & 2.73 & 2.19 & 3.37 & 6.88 & 4.77 & 6.16 & 3.72 & 5.96 & 3.20 & 4.05 & 6.80 & 9.04 \\
\hline $\mathrm{K}_{2} \mathrm{O}$ & 9.97 & 9.25 & 10.30 & 1.21 & 1.93 & 0.89 & 0.25 & 1.26 & 1.67 & 1.12 & 1.95 & 0.16 \\
\hline $\mathrm{CaO}$ & 0.16 & 0.11 & 0.22 & 0.18 & 0.17 & 0.25 & 0.14 & 0.20 & 0.10 & 0.23 & 0.22 & 0.63 \\
\hline $\mathrm{MgO}$ & 0.01 & 0.03 & 0.02 & 0.03 & 0.13 & 0.07 & 0.02 & 0.06 & 0.07 & 0.08 & 0.06 & 0.02 \\
\hline $\mathrm{MnO}$ & 0.01 & 0.01 & 0.01 & 0.01 & 0.02 & 0.01 & 0.02 & 0.02 & 0.02 & 0.02 & 0.04 & 0.03 \\
\hline $\mathrm{Cr}_{2} \mathrm{O}_{3}$ & 0.01 & 0.01 & 0.02 & 0.02 & 0.02 & 0.01 & 0.01 & 0.01 & 0.03 & 0.01 & 0.01 & 0.01 \\
\hline $\mathrm{P}_{2} \mathrm{O}_{5}$ & 0.14 & 0.14 & 0.19 & 0.11 & 0.05 & 0.05 & 0.07 & 0.05 & 0.04 & 0.03 & 0.12 & 0.07 \\
\hline $\mathrm{BaO}$ & 0.04 & 0.03 & 0.03 & 0.01 & 0.01 & 0.01 & 0.01 & 0.01 & 0.01 & 0.01 & 0.01 & 0.01 \\
\hline $\mathrm{SrO}$ & 0.02 & 0.02 & 0.02 & 0.01 & 0.01 & 0.01 & 0.01 & 0.01 & 0.01 & 0.01 & 0.01 & 0.01 \\
\hline $\mathrm{V}_{2} \mathrm{O}_{5}$ & 0.01 & 0.01 & 0.02 & 0.02 & 0.01 & 0.01 & 0.01 & 0.02 & 0.02 & 0.01 & 0.01 & 0.02 \\
\hline LOI & 0.29 & 0.38 & 0.40 & 0.32 & 1.18 & 0.49 & 0.11 & 0.65 & 0.88 & 0.68 & 0.98 & 0.14 \\
\hline Total & 99.27 & 99.08 & 99.00 & 99.97 & 99.45 & 99.76 & 100.36 & 99.56 & 99.56 & 99.52 & 100.16 & 100.06 \\
\hline
\end{tabular}


Table 2. Cont.

\begin{tabular}{|c|c|c|c|c|c|c|c|c|c|c|c|c|}
\hline \multirow{2}{*}{ Sample } & LJP-1 & LJP-2 & LJP-3 & LJP-4 & LJP-5 & LJP-6 & LJP-7 & LJP-8 & LJP-9 & LJP-10 & LJP-11 & LJP-12 \\
\hline & \multicolumn{3}{|c|}{ Wall Zone } & Core & \multicolumn{8}{|c|}{ Intermediate Zone } \\
\hline \multicolumn{13}{|c|}{ Trace elements (ppm) } \\
\hline Cs & 130 & 184.5 & 130.5 & 21.5 & 68.5 & 31.8 & 5.45 & 47.6 & 96.1 & 32.6 & 23 & 5.64 \\
\hline $\mathrm{Rb}$ & 8370 & 8940 & 9410 & 1155 & 3420 & 1520 & 198.5 & 2360 & 3510 & 1710 & 1660 & 125 \\
\hline $\mathrm{Ba}$ & 252 & 125.5 & 199.5 & 34.8 & 22.8 & 10.2 & 15.5 & 11.9 & 7.7 & 13.6 & 57.9 & 15 \\
\hline Th & 0.23 & 0.61 & 0.23 & 0.08 & 0.4 & 0.4 & 3.46 & 0.16 & 2.94 & 1.18 & 0.12 & 0.26 \\
\hline $\mathrm{U}$ & 0.66 & 0.68 & 0.37 & 0.05 & 0.53 & 0.84 & 4.19 & 0.25 & 0.6 & 3.88 & 0.09 & 1.45 \\
\hline K & 9.97 & 9.25 & 10.3 & 1.21 & 1.93 & 0.89 & 0.25 & 1.26 & 1.67 & 1.12 & 1.95 & 0.16 \\
\hline $\mathrm{Nb}$ & 1.5 & 1.5 & 2 & 2.6 & 27.2 & 16.7 & 20.5 & 17.2 & 19.5 & 60.0 & 3.9 & 9.8 \\
\hline $\mathrm{Ta}$ & 25.2 & 46.4 & 41.8 & 15.4 & 112 & 116 & 606 & 84.9 & 122 & 282 & 14.6 & 74.2 \\
\hline $\mathrm{La}$ & 1.4 & 0.9 & 1.1 & 0.6 & 0.7 & 1.2 & 3 & 1.2 & 0.9 & 0.7 & 1.8 & 0.8 \\
\hline $\mathrm{Ce}$ & 1.9 & 2 & 1.7 & 1 & 3.4 & 2.1 & 6.3 & 2.3 & 1.4 & 2.4 & 4.1 & 1.9 \\
\hline $\mathrm{Pb}$ & 7.4 & 9.1 & 5.1 & 1.1 & 2.4 & 2.5 & 4.3 & 1.7 & 1.8 & 3.4 & 1.4 & 2.4 \\
\hline $\operatorname{Pr}$ & 0.2 & 0.13 & 0.18 & 0.07 & 0.17 & 0.27 & 0.61 & 0.31 & 0.15 & 0.19 & 0.43 & 0.15 \\
\hline $\mathrm{Sr}$ & 28.9 & 19.6 & 24 & 12.6 & 6.4 & 11 & 12.5 & 13.1 & 6.1 & 11.7 & 13.9 & 39.3 \\
\hline $\mathrm{Nd}$ & 0.7 & 0.44 & 0.7 & 0.2 & 0.6 & 1 & 2.2 & 1.1 & 0.6 & 0.8 & 1.7 & 0.5 \\
\hline $\mathrm{Zr}$ & 4.0 & 3.0 & 3.0 & 2.0 & 2.0 & 2.0 & 5.0 & 2.0 & 2.0 & 8.0 & 2.0 & 2.0 \\
\hline Hf & 0.2 & 0.2 & 0.2 & 0.2 & 0.2 & 0.2 & 0.7 & 0.2 & 0.3 & 1.0 & 0.2 & 0.2 \\
\hline $\mathrm{Sm}$ & 0.2 & 0.14 & 0.21 & 0.08 & 0.16 & 0.21 & 0.49 & 0.25 & 0.19 & 0.27 & 0.47 & 0.16 \\
\hline $\mathrm{Eu}$ & 0.03 & 0.03 & 0.03 & 0.03 & 0.03 & 0.03 & 0.05 & 0.04 & 0.03 & 0.03 & 0.05 & 0.03 \\
\hline $\mathrm{Gd}$ & 0.21 & 0.11 & 0.21 & 0.12 & 0.15 & 0.19 & 0.43 & 0.24 & 0.18 & 0.43 & 0.46 & 0.17 \\
\hline $\mathrm{Tb}$ & 0.02 & 0.02 & 0.03 & 0.02 & 0.02 & 0.03 & 0.06 & 0.03 & 0.03 & 0.06 & 0.06 & 0.02 \\
\hline Dy & 0.09 & 0.1 & 0.15 & 0.09 & 0.11 & 0.15 & 0.28 & 0.16 & 0.17 & 0.36 & 0.27 & 0.1 \\
\hline $\mathrm{Ti}$ & 0.01 & 0.01 & 0.01 & 0.01 & 0.03 & 0.01 & 0.01 & 0.01 & 0.01 & 0.02 & 0.01 & 0.01 \\
\hline $\mathrm{Y}$ & 0.7 & 0.5 & 0.7 & 0.4 & 0.5 & 0.8 & 1.9 & 1.0 & 0.9 & 3.0 & 1.6 & 0.8 \\
\hline Ho & 0.02 & 0.02 & 0.03 & 0.02 & 0.02 & 0.03 & 0.05 & 0.03 & 0.03 & 0.08 & 0.04 & 0.02 \\
\hline $\mathrm{Er}$ & 0.06 & 0.06 & 0.07 & 0.06 & 0.06 & 0.07 & 0.14 & 0.07 & 0.07 & 0.21 & 0.09 & 0.06 \\
\hline $\mathrm{Tm}$ & 0.01 & 0.01 & 0.01 & 0.01 & 0.01 & 0.01 & 0.02 & 0.01 & 0.01 & 0.03 & 0.01 & 0.01 \\
\hline $\mathrm{Yb}$ & 0.06 & 0.06 & 0.06 & 0.06 & 0.06 & 0.06 & 0.12 & 0.06 & 0.06 & 0.2 & 0.06 & 0.07 \\
\hline $\mathrm{Lu}$ & 2.0 & 1.7 & 2.4 & 5.7 & 55.4 & 25.2 & 3.7 & 38.2 & 32.1 & 32.3 & 13.0 & 4.8 \\
\hline Sc & 0.1 & 0.1 & 0.1 & 0.1 & 0.7 & 0.3 & 0.1 & 0.4 & 0.3 & 0.8 & 0.2 & 0.2 \\
\hline $\mathrm{Be}$ & 3.04 & 3.24 & 4.98 & 8.47 & 6.55 & 7.32 & 16.70 & 8.13 & 6.96 & 6.95 & 7.47 & 42.0 \\
\hline Sn & 0.8 & 0.3 & 0.7 & 27.4 & 1.1 & 12.5 & 1.0 & 16.9 & 14.9 & 21.4 & 3.2 & 1.2 \\
\hline $\mathrm{Eu} / \mathrm{Eu}^{*}$ & 0.34 & 0.34 & 0.34 & 0.34 & 0.34 & 0.34 & 0.57 & 0.46 & 0.34 & 0.34 & 0.57 & 0.34 \\
\hline $\mathrm{Nb} / \mathrm{Ta}$ & 0.06 & 0.03 & 0.05 & 0.17 & 0.24 & 0.14 & 0.03 & 0.20 & 0.16 & 0.21 & 0.27 & 0.13 \\
\hline \multicolumn{13}{|c|}{ Rare earth elements ( $p p m$ ) } \\
\hline La & 1.4 & 0.9 & 1.1 & 0.6 & 0.7 & 1.2 & 3.0 & 1.2 & 0.9 & 0.7 & 1.8 & 0.8 \\
\hline $\mathrm{Ce}$ & 1.9 & 2.0 & 1.7 & 1.0 & 3.4 & 2.1 & 6.3 & 2.3 & 1.4 & 2.4 & 4.1 & 1.9 \\
\hline $\operatorname{Pr}$ & 0.2 & 0.13 & 0.18 & 0.07 & 0.17 & 0.27 & 0.61 & 0.31 & 0.15 & 0.19 & 0.43 & 0.15 \\
\hline $\mathrm{Nd}$ & 0.7 & 0.44 & 0.7 & 0.2 & 0.6 & 1.0 & 2.2 & 1.1 & 0.6 & 0.8 & 1.7 & 0.5 \\
\hline Sm & 0.2 & 0.14 & 0.21 & 0.08 & 0.16 & 0.21 & 0.49 & 0.25 & 0.19 & 0.27 & 0.47 & 0.16 \\
\hline $\mathrm{Eu}$ & 0.03 & 0.03 & 0.03 & 0.03 & 0.03 & 0.03 & 0.05 & 0.04 & 0.03 & 0.03 & 0.05 & 0.03 \\
\hline $\mathrm{Gd}$ & 0.21 & 0.11 & 0.21 & 0.12 & 0.15 & 0.19 & 0.43 & 0.24 & 0.18 & 0.43 & 0.46 & 0.17 \\
\hline $\mathrm{Tb}$ & 0.02 & 0.02 & 0.03 & 0.02 & 0.02 & 0.03 & 0.06 & 0.03 & 0.03 & 0.06 & 0.06 & 0.02 \\
\hline Dy & 0.09 & 0.1 & 0.15 & 0.09 & 0.11 & 0.15 & 0.28 & 0.16 & 0.17 & 0.36 & 0.27 & 0.1 \\
\hline Ho & 0.02 & 0.02 & 0.03 & 0.02 & 0.02 & 0.03 & 0.05 & 0.03 & 0.03 & 0.08 & 0.04 & 0.02 \\
\hline $\mathrm{Er}$ & 0.06 & 0.06 & 0.07 & 0.06 & 0.06 & 0.07 & 0.14 & 0.07 & 0.07 & 0.21 & 0.09 & 0.06 \\
\hline $\mathrm{Tm}$ & 0.01 & 0.01 & 0.01 & 0.01 & 0.01 & 0.01 & 0.02 & 0.01 & 0.01 & 0.03 & 0.01 & 0.01 \\
\hline $\mathrm{Yb}$ & 0.06 & 0.06 & 0.06 & 0.06 & 0.06 & 0.06 & 0.12 & 0.06 & 0.06 & 0.2 & 0.06 & 0.07 \\
\hline $\mathrm{Lu}$ & 0.01 & 0.01 & 0.01 & 0.01 & 0.01 & 0.01 & 0.02 & 0.01 & 0.01 & 0.03 & 0.01 & 0.01 \\
\hline
\end{tabular}

\subsection{The Major Elements}

The contents of $\mathrm{SiO}_{2}(65.73 \sim 88.75 \%), \quad \mathrm{Na}_{2} \mathrm{O}(2.19 \sim 9.04 \%), \mathrm{K}_{2} \mathrm{O}(0.16 \sim 10.30 \%)$, and $\mathrm{Na}_{2} \mathrm{O}+\mathrm{K}_{2} \mathrm{O}(3.97 \sim 13.67 \%)$ are very high, while the contents of $\mathrm{CaO}(0.10 \sim 0.63 \%)$, $\mathrm{Fe}_{2} \mathrm{O}_{3}(0.37 \sim 1.18 \%), \mathrm{MnO}(0.01 \sim 0.04 \%), \mathrm{P}_{2} \mathrm{O}_{5}(0.03 \sim 0.19 \%)$ and $\mathrm{MgO}(0.01 \sim 0.13 \%)$ is relatively low; the $\mathrm{TiO}_{2}$ content of most samples are lower than the detectable level. The ratios of $\mathrm{Al}_{2} \mathrm{O}_{3} /\left(\mathrm{CaO}+\mathrm{Na}_{2} \mathrm{O}+\mathrm{K}_{2} \mathrm{O}\right)(\mathrm{A} / \mathrm{CNK})$ range from 1.27 to 6.82 , and the ratios of $\mathrm{Al}_{2} \mathrm{O}_{3} /$ 
$\left(\mathrm{Na}_{2} \mathrm{O}+\mathrm{K}_{2} \mathrm{O}\right)(\mathrm{A} / \mathrm{NK})$ are 1.28 6.87, indicating that the Lijiapuzi pegmatites are rich in silicon and alkaline, and poor in calcium, magnesium, titanium, and phosphorus. All the samples fall in the peraluminous range in the A/NK-A/CNK diagram [30] (Figure 6). In the Harker diagram, with the increasing of content of $\mathrm{SiO}_{2}$, the contents of $\mathrm{Al}_{2} \mathrm{O}_{3}$ and $\mathrm{P}_{2} \mathrm{O}_{5}$ decrease, while $\mathrm{Fe}_{2} \mathrm{O}_{3}$ increases (Figure 7). The alkaline components are another situation. Not the content of $\mathrm{Na}_{2} \mathrm{O}$ or $\mathrm{K}_{2} \mathrm{O}$, but the sum of $\mathrm{Na}_{2} \mathrm{O}$ and $\mathrm{K}_{2} \mathrm{O}$ manifests excellent linear negative correlation with that of $\mathrm{SiO}_{2}$. Moreover, although the relationship between $\mathrm{Na}_{2} \mathrm{O}$ and $\mathrm{K}_{2} \mathrm{O}$ is not obvious, the samples from the wall zone are notably different from those of other zones, which definitely illustrate the albitization of K-feldspar (microcline). The variability of $\mathrm{CaO}, \mathrm{TiO}_{2}$ and $\mathrm{MgO}$ is not obvious.

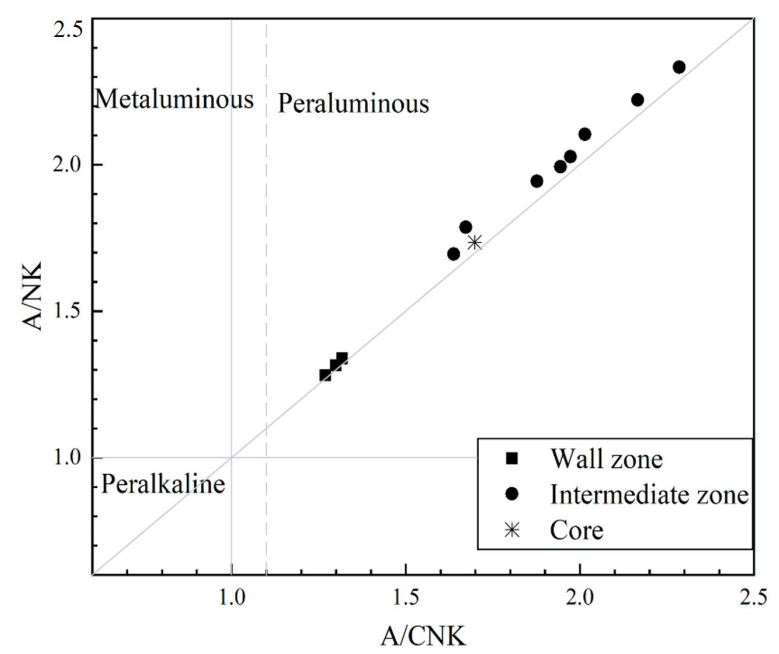

Figure 6. The A/CNK-A/NK discriminant diagram for Lijiapuzi pegmatite.
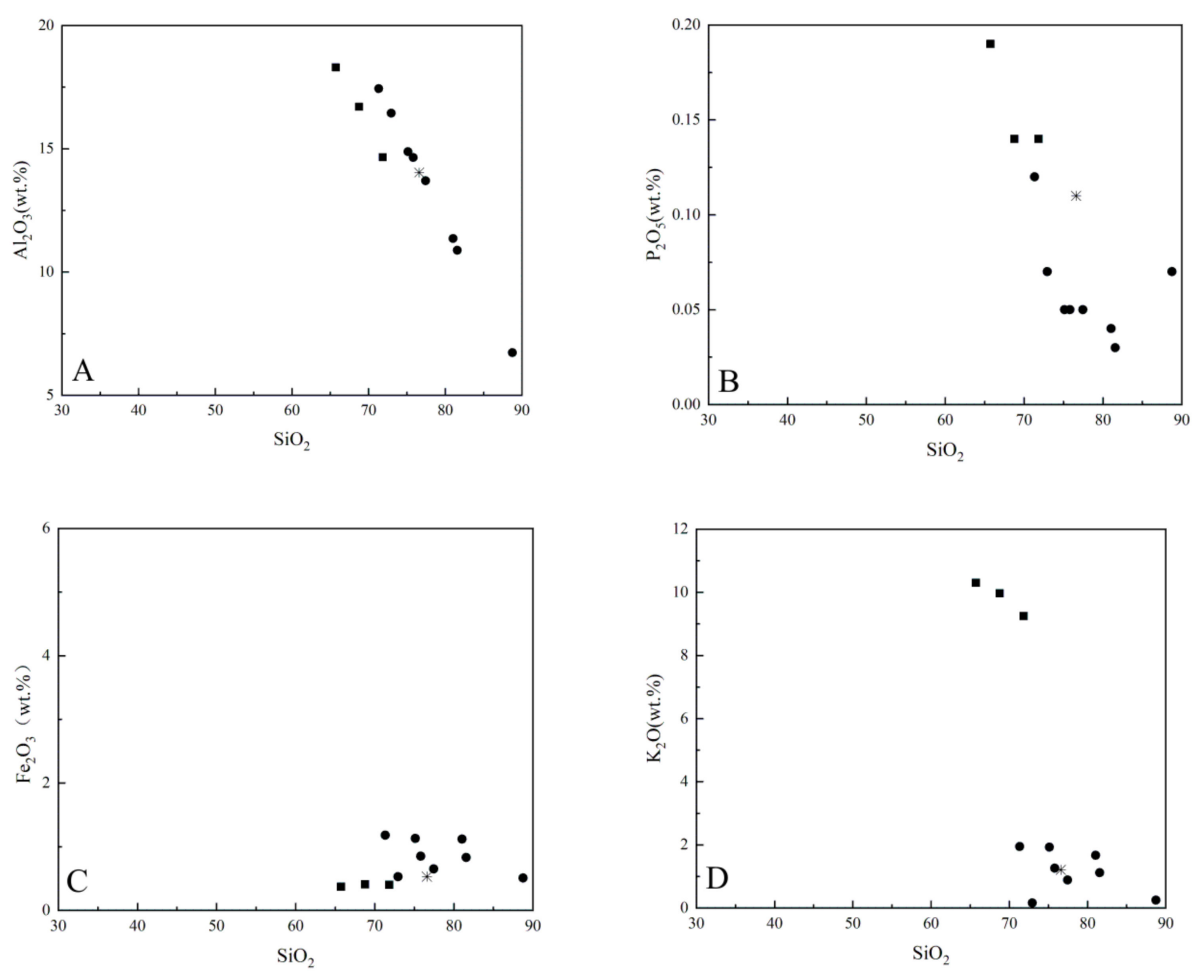

Figure 7. Cont. 

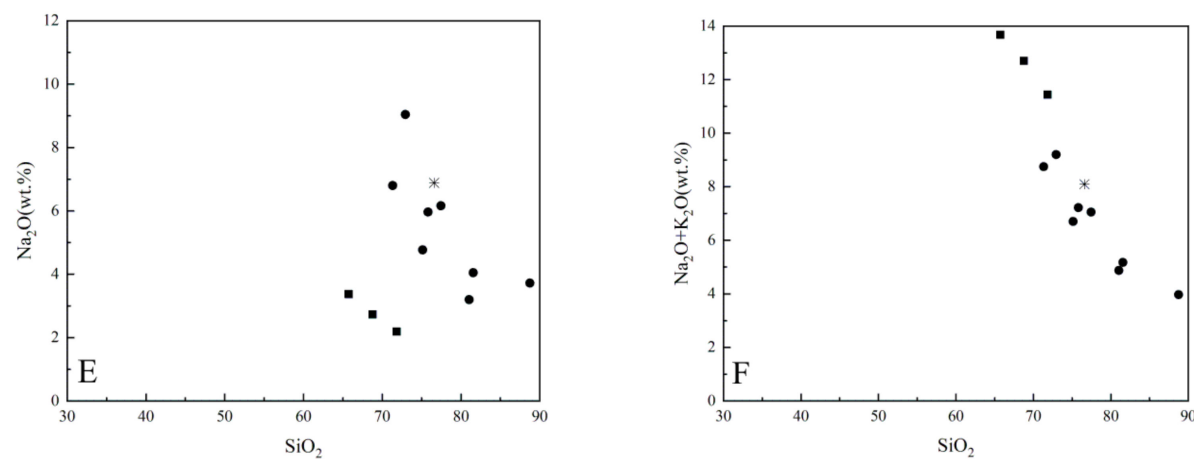

Figure 7. Harker diagram for the pegmatites in Lijiapuzi deposit. Symbols are the same as Figure 6. A-The contents of $\mathrm{Al}_{2} \mathrm{O}_{3}$ decrease with the increasing of $\mathrm{SiO}_{2}$ contents; B- The contents of $\mathrm{P}_{2} \mathrm{O}_{5}$ decrease with the increasing of $\mathrm{SiO}_{2}$ contents; $\mathrm{C}$ - The contents of $\mathrm{Fe}_{2} \mathrm{O}_{3}$ slightly increase with the increasing of $\mathrm{SiO}_{2}$ contents; $\mathrm{D} / \mathrm{E}-\mathrm{The}$ contents of $\mathrm{K}_{2} \mathrm{O}$ or $\mathrm{Na}_{2} \mathrm{O}$ show no obvious relationship to those of $\mathrm{SiO}_{2} ;$ F-The sums of $\mathrm{K}_{2} \mathrm{O}$ and $\mathrm{Na}_{2} \mathrm{O}$ decrease with the increasing of $\mathrm{SiO}_{2}$ contents.

Note that the sample of LJP-5 should be the pure quartz core (Figure 3G), but the contents of $\mathrm{Al}_{2} \mathrm{O}_{3}$ and $\mathrm{Na}_{2} \mathrm{O}$ are obviously high. This is probably due to the albite mixed in the sample, and this should not severely disturb the interpretation of trace elements and REEs.

\subsection{The Rare Earth Elements}

The total contents of rare earth elements in pegmatite range from $4.0 \times 10^{-6}$ to $3.77 \times 10^{-6}$ with an average of $5.78 \times 10^{-6}$, the light rare earth elements (LREEs) contents account for $1.98 \times 10^{-6} \sim 12.65 \times 10^{-6}$ with an average of $5.12 \times 10^{-6}$, while the heavy rare earth elements (HREEs) contents account for $0.39 \times 10^{-6} \sim 1.12 \times 10^{-6}$, with an average of $0.66 \times 10^{-6}$; the ratios of LREEs/ HREEs range from 3.14 to 11.5 , suggestive of an obvious differentiation between LREEs and HREEs.

The chondrite-normalized rare earth element (REE) diagram exhibits a conspicuous right-inclining tendency with strong Eu negative anomalies (Figure 8); however, a slight "M-type" tetrad effect still can be seen. This means the pegmatites in the Lijiapuzi deposit should have resulted from the high fractional crystallization of magma, and probably experienced strong hydrothermal fluid interaction [31].
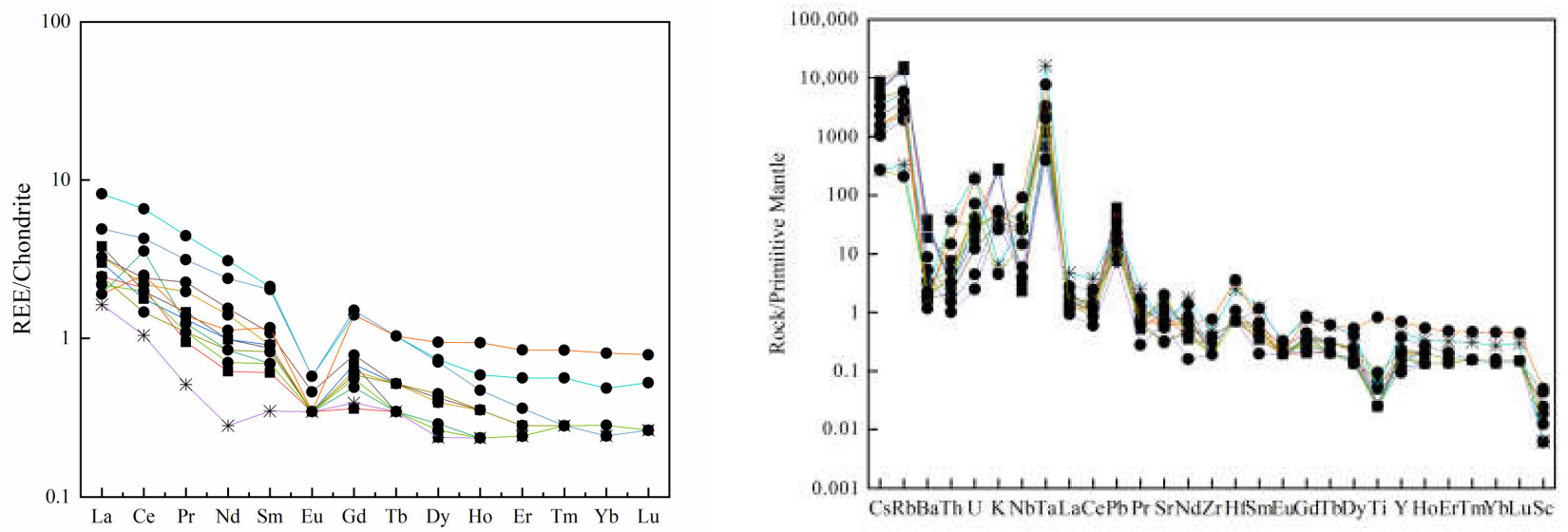

Figure 8. (Left) Chondrite normalized REE pattern; (Right) Primitive mantle normalized trace elements spidergram; Symbols are the same as Figure 6. 


\subsection{The Trace Elements}

The features of trace elements of pegmatites in the Lijiapuzi district are similar. The primitive mantle normalized trace elements spidergram shows that $\mathrm{Cs}, \mathrm{Rb}, \mathrm{K}, \mathrm{Sr}$, LREEs and $\mathrm{Ta}, \mathrm{Pb}, \mathrm{U}$ etc. are enriched, while $\mathrm{Zr}, \mathrm{Eu}, \mathrm{Ti}, \mathrm{Sc}, \mathrm{Yb}$ are depleted (Figure 8). The sharp Ti depletion indicates that perhaps a crust-derived substance participated in magmatic activity and probably experienced the fractional crystallization of ilmenite. The ratio of $\mathrm{Nb}$ / Ta ranges from 0.032 to 13.0 , which is much lower than that of primitive mantle and chondrite; this means the parental magma of the pegmatites was probably crustrather than mantle- derived. The ratio of $\mathrm{Rb} / \mathrm{Sr}$ ranges from 3.18 to 575.41 , which is much higher than that of primitive mantle, which has an average of 0.029 , suggesting that the pegmatites resulted from the high differentiation of magma and experienced the fractional crystallization of plagioclase.

The comparation of particular trace elements among various zones is more indicative of the metallogeny. In contrast with the samples of the wall zone, the contents of Cs, U, $\mathrm{Th}$, Be and Sn of the intermediate zone and quartz core significantly increase, which is well in accordance with the mineral assemblages mentioned above. This means that the pegmatites of Lijiapuzi are confirmed to be of the LCT type.

Note that the characteristics of the trace and rare earth elements of samples from three distinct zones are almost the same, which indicates that the features of the elements can be used to the provenance and the tectonic study setting of the pegmatoid rocks in the Lijiapuzi district.

\section{Discussion}

\subsection{Petrogenesis of Pegmatites}

Currently, the classification scheme of granite accepted by most scholars is to be I, S, $\mathrm{A}$, and $\mathrm{M}$ type [32], and the Amphibole, Cordierite and alkaline mafic minerals are the crucial classification criteria [33]. In the Lijiapuzi mining district, field and microscopic observation indicates that there are minor mafic minerals in pegmatites, and the pegmatites belong to peraluminous rocks in the A/NK-A/CNK diagram (Figure 6). Accordingly, as a result of geochemical assay, the contents of $\mathrm{Fe}_{2} \mathrm{O}_{3}(0.37 \sim 1.18 \%), \mathrm{MnO}(0.01 \sim 0.04 \%)$ and $\mathrm{MgO}(0.01 \sim 0.13 \%)$ in $\mathrm{Nb}$-Ta bearing pegmatites are very low; the content of $\mathrm{Ti}$ is lower than the detectable level. This means that the pegmatites belong to a crust-derived, S-type granitoid.

The pegmatites are enriched in LILEs such as $\mathrm{Cs}, \mathrm{Rb}, \mathrm{K}$ and $\mathrm{Sr}$ and depleted in HFSEs such as $\mathrm{Zr}$, Ti and Sc (Figure 8). The high ratio of $\mathrm{Rb} / \mathrm{Sr}$ indicates that there was probably fractional crystallization of plagioclase. The low amount of $\mathrm{Yb}\left(0.06 \sim 0.12 \times 10^{-6}\right)$ and $\mathrm{Y}$ $\left(0.4 \sim 3.0 \times 10^{-6}\right)$, and the distinct differentiation between LREEs and HREEs with obvious Eu negative anomalies and the right-inclined REE normalized pattern imply that there should be garnet residue in the source magma [34]. The lower ratio of $\mathrm{Nb} / \mathrm{Ta}$ and the higher ratio of $\mathrm{La} / \mathrm{Nb}$ and $\mathrm{Rb} / \mathrm{Sr}$ indicate that the pegmatites in Lijiapuzi should be of upper crustal origin $[35,36]$.

It should be pointed out that the Ti contents of most of the samples in Lijiapuzi district are lower than the detectable level. The sharp Ti depletion probably indicates that rutile remained as a residual phase during the partial melting. It is well known that the cation radii of $\mathrm{Nb}^{+5}$, $\mathrm{Ta}^{+5}$ and $\mathrm{Ti}^{+4}$ are almost the same, as $\mathrm{Nb}^{+5}$ and/or $\mathrm{Ta}^{+5}$ tends to strongly partition into rutile in the crystalline phase $[37,38]$. Furthermore the rutile incorporates $\mathrm{Nb}$ preferentially over $\mathrm{Ta}$, and this explains the enrichment of Ta over $\mathrm{Nb}$ in highly fractionated granitic rocks [39] and also the pegmatoid rocks in the Lijiapuzi deposit.

\subsection{Tectonic Setting}

Granitoid rocks can be used to discriminate the petrogenetic tectonic setting [8,40-42], and some scholars have strongly advocated a classification scheme of $\mathrm{Nb}$-Ta bearing pegmatites by their tectonic setting to better understand the granitic pegmatite deposits [43]. In other words, the tectonic setting is of great importance to the metallogeny of ore deposits. 
In the $\mathrm{Y} v \mathrm{vs} . \mathrm{Nb}$ diagram, all of the pegmatitic rocks fall in the volcanic arc and syncollision granite zone, in the $\mathrm{Nb}+\mathrm{Y}$ vs. Rb diagram they mostly fall in the syn-collision granite zone with two rocks on the boundary line between sys-collision and volcanic arc granite zone, i.e., the pegmatite should be formed in the synorogenic tectonic setting. In the $\mathrm{Yb}$ vs. Ta diagram, most rocks fall in syn-collision granite zone, with two in the within-plate-granites zone, however, in the $\mathrm{Yb}+\mathrm{Ta}$ vs. Rb diagram, rocks falling in the syn-collision granites zone and the within-plate granite zone are almost the same (Figure 9).
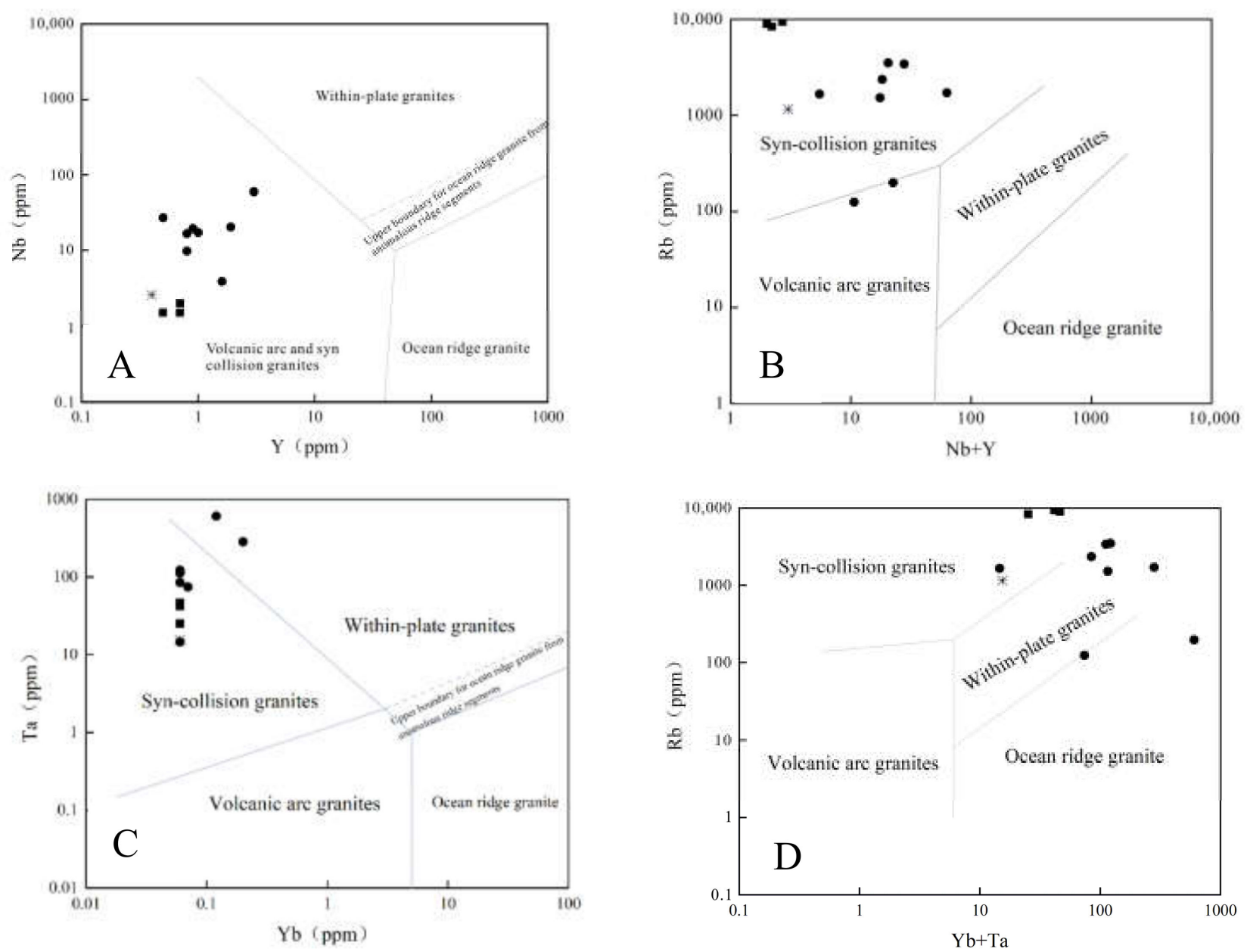

Figure 9. Tectonic discriminant diagrams of WPG and syn-GOLG suites of the Kenticha granitepegmatite; Symbols are the same as Figure 6. A-All the rock samples fall in volcanic arc and syn-collision granites domain; B-Most of the rock samples fall in syn-collision granites domain; C-Most of the rock samples fall in syn-collision granites domain; D-Parts of the rock samples fall in syn-collision granites domain, while others fall in within-plate granites domain except for one outlier. The combination of the four subfigures indicates that the pegmatites in Lijiapuzi should be related to orogenesis.

NCC, where the Liijiapuzi ore deposit is located, is a relatively stable block. The ancient Archean basic volcano-sedimentary strata experienced intense regional metamorphism and migmatism. As for the eastern Liaoning area, the thickest central part of the Proterozoic Liaohe group occurred as a result of there being intensely metamorphic volcanic rocks at the bottom and slightly metamorphic sedimentary rocks at the top. The unique lithologic sequences earned the name of "Liaodong rift" [44], whose forming mechanism is still controversial, as there is some question as to whether it resulted from the continental rift $[45,46]$ or as the result of a modern plate collision [47-49]. However, there seems to 
be a consensus that the eastern Liaoning area was under the extensional tectonic setting in the paleo-Proterozoic era. The Lijiapuzi pegmatites clearly occurred as dikes and lens, indicating a relatively extensional environment. In summary, the Lijiapuzi $\mathrm{Nb}$-Ta deposit was formed in a relatively extensional environment of the post-orogenic stage.

\subsection{Nb-Ta Mineralization in Lijiapuzi Pegmatite Deposit}

The $\mathrm{Nb}$-Ta mineralization of pegmatite has long been disputed by many scholars worldwide. Magmatic crystallization differentiation was firstly promoted as the main rare-metal mineralization mechanism [50-52], but later many scholars found that the post-magmatic hydrothermal fluids and the late-stage metasomatism play an important role in the mineralization [53,54]. Currently, both of the mechanisms are advocated by most geologists [55-57], especially the post-magmatic supercritical fluid [58,59] and the albitization [56,57].

Field truth and microscopic observation indicate that the Lijiapuzi pegmatites exhibit obvious albitization of microcline and late-stage uranium mineralization superimposition. The $\mathrm{Nb}$-Ta mineralization is intimately related to the albite metasomatism of the intermediate muscovite (lepidolite) -albite zone. The features of major components and trace elements indicate that the Lijiapuzi pegmatite was of crust-derived origin, and the residual rutile fractionated the $\mathrm{Nb}$ and $\mathrm{Ta}$ in the peraluminous granitic melts and formed in a relatively extensional environment of the post-orogenic tectonic setting, i.e., the Lijiapuzi $\mathrm{Nb}$-Ta deposit was formed by the albitization processes of pegmatite in a post- orogenic collision setting in the eastern margin of NCC was and superimposed by a slightly late-stage uranium mineralization.

\subsection{Implications for Nb-Ta Mineral Resource Potential in Lijiapuzi District}

As mentioned above, the popular classification scheme of grantic pegmatites today gradually turns from the inferred depth-zone dependent criterion to the measurable CMS (Chemical composition-Mineral assemblage-Structural geology) criterion, with emphasis on the practical application [11,12]. However, no one unique classification scheme can include all of the pegmatiod rocks up to now [11].

Beskin and Marin discovered in their research on rare metal mineralization in Eastern Transbaikalia that the LCT pegmatites should further be divided into two types: a "multicomponent rare metal type" and an "albite-spodumene pegmatite" [60,61]. The former occurs as a large crystal with obvious zoning, of a relatively small scale and is usually localized in the upper part of the region, while the latter manifests as multiple extended dikes with no zoning, huge length, and usually locates in the underlying part of the former. Actually the long dikes are not pegmatite but granites serving as the "parent magma" of the multicomponent rare metal. These two kinds of pegmatoid rocks were rare metal mineralized. From this point of view, the classification is surely indicative of ore prospecting.

The NW-trending pegmatites in Lijiapuzi are shorter, thicker, obvious-zoning and localized in the upper part of the near-surface, while the NE-trending pegmatites are longer, thinner, devoid of zoning and localized in the lower part of the district. This probably means that there is excellent ore prospecting potential in the lower part of the Lijiapuzi district.

\section{Conclusions}

(1) The $\mathrm{Nb}$-Ta bearing pegmatites in Lijiapuzi are mainly composed of coarse-grained microcline, albite, muscovite, lepidolite, quartz, spodumene, and apatite, with minor beryl, gahnite, cassiterite and zircon and fine-grained tantalite, columbite, microlite, goethite and uranium minerals. The rare metal bearing pegmatites belong to the LCT-type deposit. The $\mathrm{Nb}$-Ta mineralization mainly occurred in the process of albitization in the intermediate zone, and was superimposed by a late-stage uranium mineralization. 
(2) The lithogeochemical features indicate that Lijiapuzi pegmatoids are rich in silicon and alkaline, poor in calcium, magnesium, titanium, and phosphorus, and belong to peraluminous granitoid rocks. The enrichment of LILEs and the depletion of HFSEs, the distinct right-inclined REE pattern with obvious Eu negative anomaly, lower ratio of $\mathrm{Nb} / \mathrm{Ta}$ and higher ratio of $\mathrm{La} / \mathrm{Nb}$ and $\mathrm{Rb} / \mathrm{Sr}$ indicate that the pegmatites were of a crustal origin and formed in relatively extensional tectonic setting of post-orogenesis.

(3) There are two kinds of pegmatites in the Lijiapuzi district, i.e., the NW-trending pegmatites, which are shorter, thicker, obvious-zoning and localized in the upper part of the near-surface, and the NE-trending pegmatites are longer, thinner, devoid of zoning and are localized in the lower part of the district. This probably means that there is excellent ore prospecting potential in the lower part of the Lijiapuzi district.

Author Contributions: Writing-original draft preparation, J.F.; writing—review and editing, Y.Y.; visualization, J.L.; data curation, Z.L.; investigation, S.J. and Y.P. All authors have read and agreed to the published version of the manuscript.

Funding: This research was funded by the National Key Research and Development Program of China (grant number: 2017YFC1503105).

Acknowledgments: The authors were deeply indebted to Yonghong Zhang, the director of No.101 Geology Team Co., Ltd., Liaoning Nonferrous Geology Bureau, for his kind help in field investigation. The authors are very grateful to three anonymous reviewers for their constructive comments that greatly help us to improve the original version of the manuscript.

Conflicts of Interest: The authors declare that they have no conflicts of interest.

\section{References}

1. Linnen, R.L.; Van Lichtervelde, M.; Černý, P. Granitic pegmatites as sources of strategic metals. Elements 2012, 8, 275-280. [CrossRef]

2. London, D. Ore-forming processes within granitic pegmatites. Ore Geol. Rev. 2018, 101, 349-383. [CrossRef]

3. Mackay, D.A.R.; Simandl, G.J. Geology, market and supply chain of niobium and tantalum-A review. Miner. Depos. 2014, 49, 1025-1047. [CrossRef]

4. $\quad$ Linnen, R.; Trueman, D.; Burt, R. Tantalum and niobium. In Critical Metal Handbook; Gunn, G., Ed.; John Wiley \& Sons, Ltd.: West Sussex, UK, 2014; pp. 361-384.

5. Krishnamurthy, P. Rare metal and rare earth element resources: World scenario with special reference to India. J. Geol. Soc. India 2020, 95, 465-474. [CrossRef]

6. Simandl, G.J.; Burt, R.O.; Trueman, D.L.; Paradis, S. Economic geology models 4. Tantalum and niobium: Deposits, resources, exploration methods and market-A primer for geoscientists. Geosci. Can. 2018, 45, 85-96. [CrossRef]

7. Simmons, W.B.; Webber, K.L. Pegmatite genesis: State of the art. Eur. J. Mineral. 2008, 20, 421-438. [CrossRef]

8. Černy, P. Rare-element granitic pegmatite. Part II: Regional to global environments and pretrogenesis. Geosci. Can. 1991, 18, 68-81.

9. Landes, K.K. Origin and classification of pegmatites. Am. Miner. 1933, 18, 33-56.

10. London, D. Pegmatites; The Canadian Mineralogist, Special Publication 10; Mineralogical Association of Canada: Quebec City, QC, Canada, 2008; pp. 1-308.

11. Dill, H.G. The CMS classification scheme (Chemical composition-Mineral assemblage—Structural geology)—linking geology to mineralogy of pegmatitic and aplitic rocks. J. Min. Geochem. 2016, 193, 231-263. [CrossRef]

12. Müller, A.; Simmons, W.; Beurlen, H.; Thomas, R.; Ihlen, P.M.; Wise, M.; Roda-Robles, E.; Neiva, A.M.R.; Zagorsky, V. A proposed new mineralogical classification system for granitic pegmatites-Part I: History and the need for a new classification. Can. Mineral. 2018, 56, 1-25.

13. Černy, P. Rare-element granitic pegmatite. Part I: Anatomy and internal evolution of pegmatite deposits. Geosci. Can. 1991, 18, 49-67.

14. Černy, P.; Ercit, T.S. The classification of granitic pegmatites revisited. Can. Mineral. 2005, 43, 2005-2026. [CrossRef]

15. Li, J.K.; Li, P.; Wang, D.H. A review of niobium and tantalum metallogenic regularity in China. Chin. Sci. Bull. 2019, 64, 1545-1566. [CrossRef]

16. Wang, R.C.; Che, X.D.; Wu, B. Critical mineral resources of Nb, Ta, Zr, and Hf in China. Chin. Sci. Bull. 2020, 65, 3763-3777. [CrossRef]

17. Zhang, L.; Lin, D.S. Current situation of rare metal resources in China. Geol. Prosp. 2004, 40, $26-30$.

18. Zhu, J.C.; Wu, C.N.; Liu, C.S.; Li, F.C.; Huang, X.L.; Zhou, D.S. Magmatic-hydrothermal evolution and genesis of Koktokay No.3 rare metal pegmatite dyke, Altai, China. Geol. J. China Univ. 2000, 6, 40-51. 
19. Zhou, Q.F.; Qin, K.Z.; Tang, D.M.; Ding, J.G.; Guo, Z.L. Mineralogy and significance of micas and feldspars from the Koktokay No. 3 pegmatitic rare-element deposit, Altai. Acta Petrol. Sin. 2013, 29, 3004-3022.

20. Liu, X.; Zhou, F.C.; Huang, Z.B.; Li, J.K.; Zhou, H.X.; Xiao, G.Q.; Bao, Y.H.; Li, P.; Tan, L.M.; Shi, W.K.; et al. Discovery of Renli Superlarge pegmatite-type $\mathrm{Nb}$-Ta polymetallic deposit in Pingiiang, Hunan Province and its significances. Geotecton. Metallog. 2018, 42, 235-243.

21. Gao, Y.; Sun, Y.; Zhao, Z.; Li, J.K.; He, H.H.; Yang, Y.Q. ${ }^{40} \mathrm{Ar}-{ }^{39} \mathrm{Ar}$ dating of muscovite from the Zhaojinggou Nb-Ta polymetallic deposit in Wuchuan county of Inner Mongolia and its geological implications. Rock Mineral. Anal. 2017, 36, 551-558.

22. Li, Z.D.; Li, X.G.; Cui, Y.R.; Li, G.Z.; Zhang, J.; Guo, H.; Liu, W.G.; Zhang, C.; Yu, R.G.; Xie, Y.; et al. Yanshanian mineralization of Zhaojinggou $\mathrm{Nb}$-Ta deposit, Inner Mongolia: Evidences from the monazite and zircon LA-MC-ICP-MS U-Pb and biotite ${ }^{40} \mathrm{Ar}-$ ${ }^{39}$ Ar geochronology. Earth Sci. 2019, 4, 234-247.

23. Zhao, G.C.; Cawood, P.A.; Wilde, S.A.; Sun, M.; Lu, L.Z. Metamorphism of basement rocks in the Central Zone of the North China Craton: Implications for Paleoproterozoic tectonic evolution. Precam. Res. 2000, 103, 55-88. [CrossRef]

24. Pirajno, F. The Geology and Tectonic Settings of China's Mineral Deposits; Springer: Berlin/Heidelberg, Germany, 2013 ; pp. 35-118.

25. Li, S.R.; Santosh, M. Metallogeny and craton destruction: Record from the North China Craton. Ore Geol. Rev. 2014, 56, 376-414. [CrossRef]

26. Zhu, R.X.; Fan, H.R.; Li, J.W.; Meng, Q.R.; Li, S.R.; Zeng, Q.D. Decratonic gold deposits. Sci. China Earth Sci. 2015, 58, 1253-1537. [CrossRef]

27. Diao, C.C.; Feng, J.L.; Yu, J.H.; Zhu, X.Z. Geological characteristics of the Lijiapuzi niobium-tantalum deposit in Xinbin County, Liaoning Province. Geol. Res. 2013, 22, 20-24.

28. Pang, Y.M. Metallogenic Regularity of Lijiapuzi Nb-Ta Deposit, Xinbin, Liaoning Province. Master's Thesis, Northeastern University, Shenyang, China, June 2021.

29. Pirajno, F. Hydrothermal Processes and Mineral Systems; Springer: Dordrecht, The Netherlands, 2009; pp. $1213-1241$.

30. Maniar, P.D.; Piccoli, P.M. Tectonic discrimination of granitoids. Geol. Soc. Amer. Bull. 1989, 101, 635-643. [CrossRef]

31. Wu, F.Y.; Jahn, B.M.; Wilde, S.A.; Lo, C.H.; Yui, T.F.; Lin, Q.; Ge, W.C.; Sun, D.Y. Highly fractionated I-type granites in NE China (I): Geochronology and petrogenesis. Lithos 2003, 66, 241-273. [CrossRef]

32. Bonin, B. A-type granites and related rocks: Evolution of a concept, prospects. Lithos 2007, 97, 1-29. [CrossRef]

33. Miller, C.F. Are strongly petaluminous magmas derived from politic sedimentary sources? J. Geol. 1985, 93, 673-689. [CrossRef]

34. Defant, M.J.; Xu, J.F.; Kepezhinskas, P. Adakites: Some variations on a theme. Acta Petrol. Sin. 2002, 18, $129-142$.

35. Taylor, S.R.; Mclennan, S.M. The geochemical evolution of the continental crust. Rev. Geophys. 1995, 33, 241-265. [CrossRef]

36. Mcdonough, W.F. Compositional model for the earth's core. In Treatise on Geochemistry; Davis, M.A., Ed.; Elsevier: Amsterdam, The Netherlands, 2013; Volume 2, pp. 547-568.

37. Horng, W.S.; Hess, P.C.; Gan, H. The interactions between $\mathrm{M}^{+5}$ cations $\left(\mathrm{Nb}^{+5}, \mathrm{Ta}^{+5}\right.$, or $\left.\mathrm{P}^{+5}\right)$ and anhydrous haplogranite melts Geochim. Cosmochim. Acta 1999, 63, 2419-2428. [CrossRef]

38. Xiong, X.L.; Adam, J.; Green, T.H. Rutile stability and rutile/melt HFSE partitioning during partial melting of hydrous basalt: Implications for TTG genesis. Chem. Geol. 2005, 218, 339-359. [CrossRef]

39. Linnen, R.L.; Keppler, H. Columbite solubility in granitic melts: Consequences for the enrichment and fractionation of $\mathrm{Nb}$ and Ta in the Earth's crust. Contrib. Mineral. Petrol. 1997, 128, 213-227. [CrossRef]

40. Pearce, J.A.; Harris, N.G.W.; Tindle, A.G. Trace element discrimination diagrams for the tectonic interpretation of granitic rocks. J. Pet. 1984, 25, 956-983. [CrossRef]

41. Whalen, J.B.; Currie, K.L.; Chappell, B.W. A-type granites: Geochemical characteristics, discrimination and petrogenesis. Contrib. Mineral. Petrol. 1987, 95, 407-419. [CrossRef]

42. Chappell, B.W.; White, A.J.R. I- and S-type granites in the Lachlan Fold Belt. Trans. Royal Soc. Edinb. Earth Sci. 1992, 83, 1-26. [CrossRef]

43. Hou, J.L. The Comparative Study of Diagenetic, Metallogenic Characteristics and Tectonic Environment of Two Kinds of Pegmatites in China. Ph.D. Thesis, Chinese Academy of Geological Sciences, Beijing, China, May 2018.

44. Chen, R.D. A paleo-Proterozoic rift basin: Liaodong rift. Liaoning Geol. 1984, 2, 126-133.

45. Chen, R.D. Geological tectonic evolution of Liaodong rift. Reg. Geol. China 1990, 4, 306-315.

46. Chen, R.D.; Li, X.D.; Zhang, F.S. Several problems about the paleo-Proterozoic geology of eastern Liaodong. Geol. China 2003, 30, 207-213.

47. Wan, Y.S.; Song, B.; Yang, C.; Liu, D.Y. Zircon SHRIMP U-Pb geochronogy of Archean rocks from the Fushun-Qingyuan area, Liaoning Province and its geological significance. ACTA Geol. Sin. 2005, 79, 78-86.

48. Dong, C.Y.; Ma, M.Z.; Liu, S.J.; Xie, H.Q.; Liu, D.Y.; Li, X.M.; Wan, Y.S. Middle Paleoproterozoic crustal extensional regime in the North China Craton: New evidence from SHRIMP zircon U-Pb dating and whole-rock geochemistry of metagabbro in the Anshan- Gongchangling area. Acta Petrol. Sin. 2012, 28, 2785-2792.

49. Bi, J.H.; Xing, D.H.; Ge, W.C.; Yang, H.; Dong, Y. Age and tectonic setting of meta-acid volcanic rocks from the North Liaohe Group in the Liaodong area: Paleoproterozoic intracontinental rift or active continental margin? Earth Sci. Front. 2018, 25, 295-308.

50. Cuney, M.; Marignac, C.; Weisbrod, A. The Besuvoir topaz-lepidolite albite granite (Massif Central, France): The disseminated magrnatic Sn-Li-Ta-Nb-Be mineralization. Econ. Geol. 1992, 87, 1766-1794. [CrossRef] 
51. Raimbault, L.; Cuney, M.; Azeacott, C.; Duthou, J.L.; Joron, J.L. Geochemical evidence for a multistage magmatic genesis of Ta-Sn-Li mineralization in the granite at Beauvoir, French Massif Central. Econ. Geol. 1995, 90, 548-576. [CrossRef]

52. Zhu, J.C.; Li, R.K.; Li, F.C.; Xiong, X.L.; Zhou, F.Y.; Huang, X.L. Topaz-albite granites and rare-metal mineralization in the Limu district, Guangxi Province, southeast China. Miner. Depos. 2001, 36, 393-405. [CrossRef]

53. Kempe, U.; Gotze, J.; Dandar, S.; Habermlann, D. Magmatic and metasomatic processes during formation of the Nb-Zr-REE deposits Khaldzan Buregtz and Tsakhir (Mongolian Altai): Indications from a combined CL-SEM study. Mineral. Mag. 1999, 63, 165-177. [CrossRef]

54. Salvi, S.; Williams-Jones, A.E. Alteration, HFSE mineralization and hydrocarbon formation in peralkaline igneous systems: Insights from the Strange Lake Pluton, Canada. Lithos 2006, 91, 19-34. [CrossRef]

55. Wang, F.L.; Zhao, T.P.; Chen, W. Advances in study of Nb-Ta ore deposits in Panxi area and tentative discussion on genesis of these ore deposits. Miner. Depos. 2012, 31, 293-308.

56. Huang, X.E.; Xu, Z.H. Metasomatism and its relationship to rare metal mineralization of Yashan granite, Jiangshan. Jiangxi Nonferrous Met. 2005, 8, 1-4.

57. Wang, Y.R.; Li, J.T.; Lu, J.L.; Fan, W.L. Geochemical mechanism of Nb-Ta mineralization during the late stage of granite crystallization. Geochem 1982, 1, 175-185.

58. Qiu, R.Z.; Zhou, S.; Chang, H.L.; Du, S.H.; Peng, S.B. Role of the supercritical fluid in the process of granitic rock-forming and mineralization: Taking the granitic Nb-Ta deposit in Xianghualing area as an example. Geol. Sci. Technol. Info. 1998, 17, 40-44.

59. Qiu, R.Z.; Peng, S.B.; Du, S.H. Genesis of granitic Nb-Ta deposit in Xianghualing area and the role of the supercritical fluid in the process of rock-forming and mineralization. Hunan Geol. 1997, 16, 92-97.

60. Beskin, S.M.; Marin, Y.B. Classification of granitic pegmatites and pegmatite-bearing granitic systems. Geol. Ore Depos. 2018, 60, 578-586. [CrossRef]

61. Beskin, S.M.; Marin, Y.B. Granite systems with rare-metal pegmatites. Geol. Ore Depos. 2020, 62, 554-563. [CrossRef] 